\title{
Определение формы кристаллов породообразующих минералов из интрузии Мончеплутон (северо-восточная Фенноскандия) с помощью автоматического расчета фрактальных размерностей
}

\author{
Хубер М., Степневская К. \\ Кафедра геологии, почвоведения и геоинформации, факультет наук о Земле и пространственного \\ управления, Университет Марии Кюри-Склодовской, Люблин, Польша, mhuber@uтcs.pl
}

Аннотация. В статье описано применение метода оценки фрактальной размерности к исследованиям минералов и влияние вторичных процессов минералообразования на результат. Было исследовано 38 образцов, содержащих породообразующие минералы, из палеопротерозойской интрузии Мончеплутон, расположенной на северо-востоке Фенноскандии. Чтобы выполнить измерения и правильно интерпретировать породы, было проведено петрографическое исследование образцов с использованием поляризационной микроскопии, а затем измерена размерность фрактальной ячейки с использованием автоматизированного метода расчета сторон сетки, которая была наложена на микрофотографию, показывающую микроскопические изображения минералов. Полученный коэффициент фрактальной размерности коррелирует с формой исследуемых минералов в породе.

Ключевые слова: Фрактальная размерность, породообразующие минералы, Мончеплутон, СевероВосточная Фенноскандия.

\section{Determination of the shape of crystals of the rock-forming minerals from the Monchepluton intrusion (NE Fennoscandia) using automatic calculation of fractal dimensions}

\author{
Huber M., Stępniewska K. \\ Department of Geology, Soil Science and Geoinformation, Earth Science and Spatial Management \\ Faculty, Maria Curie-Sklodowska UniversityLublin,Poland,mhuber@umcs.pl
}

\begin{abstract}
The paper aims at applying the fractal dimension estimation method to the investigations of minerals and influence of secondary processes on their shapes. For this purpose, 38 samples of rock-forming minerals from the Monchepluton, a Paleoproterozoic PGE-bearing layered intrusion that occurs in the NE Fennoscandia, were analyzed. The samples primarily underwent a petrographic analysis using polarization microscopy for a correct interpretation of rocks. Further, the fractal-box dimension was measured by means of an automated calculation technique applied for the sides of a grid which was superimposed on a micrograph with a microscopic image of a mineral. The derived fractal dimension coefficients were correlated with the shape of the examined minerals in the rocks.
\end{abstract}

Key words: Fractal dimension, rock-forming minerals, Monchepluton, NE Fennoscandia.

\section{Introduction}

The shape of rock-forming minerals depends on various processes that took place in the rock. These processes include magma melting, differentiation, crystallization, and secondary transformations of the rock after emplacement. All these factors have a significant impact on mineralogical, petrographic and reservoir studies aiming at the identification of the impact limits of the geological processes in the rocks in question. They may be directly correlated with changes in the structure and texture of the rock-forming minerals that compose the rocks. Mathematizing the shape of the corresponding indicator minerals enables simply processing these data. The application of fractal-box dimension for calculating the shape of minerals is a relatively trivial calculating operation enabled by various software applications.

The results of such calculations can further be processed, correlated with each other and visualized by obtaining data that can easily be superimposed on a geological map of a massif to draw a range of the observed transformations in the discussed rocks. In Earth sciences, the fractal dimension has long 


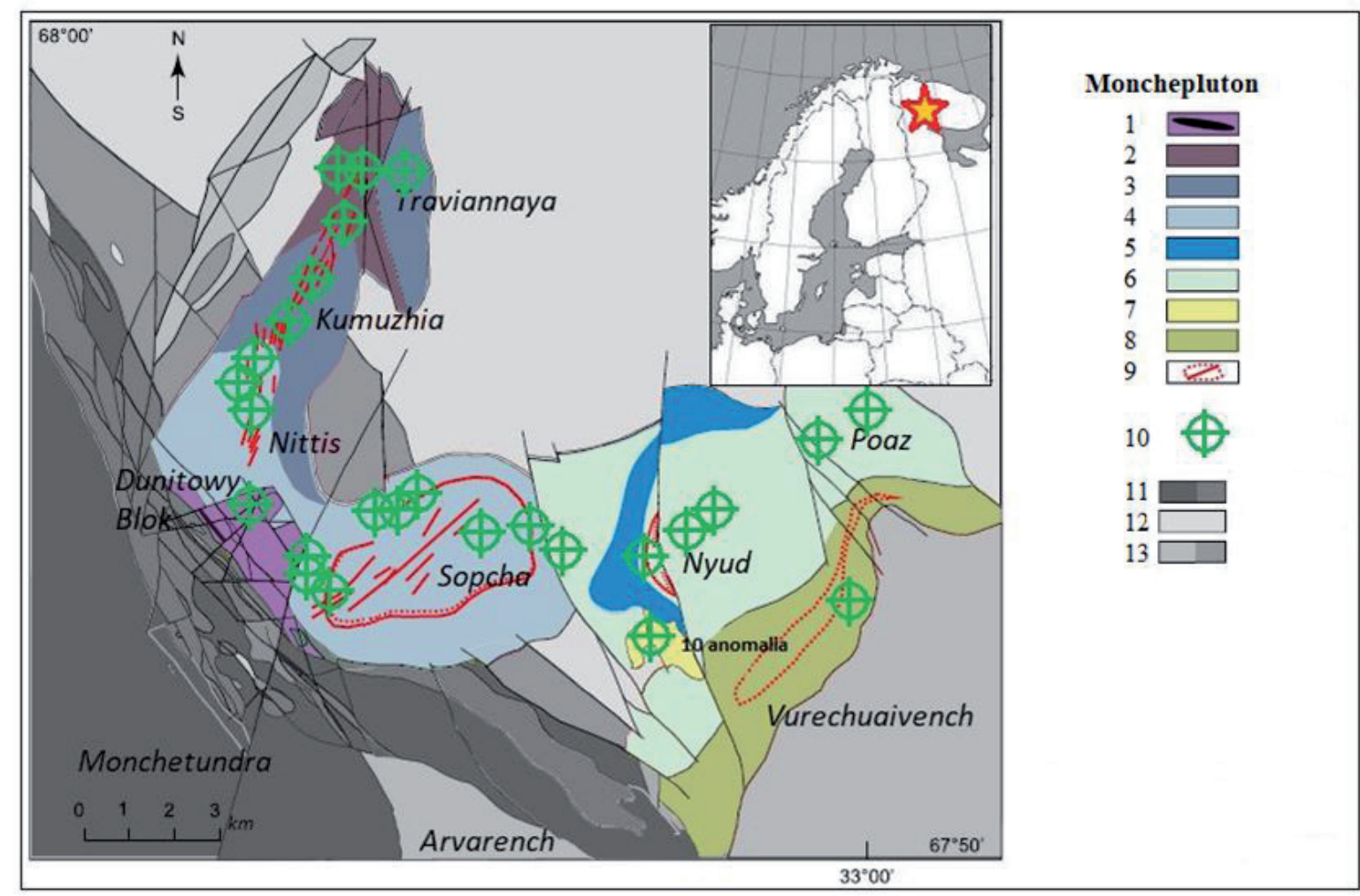

Fig. 1. Sketch map of the Monchepluton intrusion (according to Mitrofanov, Smolkin 2004; simplified by the authors) and sampling points.

1 - dunite, chromitite, 2 - harzburgite, 3 - other peridotites, 4 - orthopyroxenite, 5 - norite, olivine norite, 6 - gabbronorite, 7 - gabbro, 8 - anorthosite, 9 - sulfide ore mineralization, 10 - sampling points, 11 - rocks of the Monchetudra massif, 12 - rocks of the Imandra-Varzuga Belt, 13 - rocks of the Kola Series.

Рис. 1. Схематическая карта вторжения Мончеплутона (по Митрофанову, Смолкину, 2004; упрощено авторами) и точки отбора проб.

1 - дунит, хромитит, 2 - гарцбургит, 3 - другие перидотиты, 4 - ортопироксенит, 5 - норит, оливин-норит, 6 - габбронорит, 7 - габбро, 8 - анортозит, 9 - сульфидная рудная минерализация, 10 - точки отбора проб, 11 - породы массива Мончетудра, 12 - породы пояса Имандра-Варзуга, 13 - породы Кольской серии.

been used in the assessment of rock porosity (Chen et al., 2021; Gulbin, Evabgulova, 2003; Kincal et al., 2010; Lehmann et al., 2003; Martin, Reyes, 2008), geophysical and reservoir (Mohammadi et al., 2013; Zhengli et al., 2014), tectonic (Sły et al., 2014), and textural studies of rocks (Gerig et al., 2010; Singh et al., 2021; Voytekhovsky et al., 1997; Zheru et al., 2001). The correlation of the shape of rock-forming minerals in the context of the petrographic description of rocks is still quite poorly understood. This paper aims at studying the fractal dimension of rock-forming minerals and interpreting the results in terms of the advancement of secondary processes in the Paleoproterozoic PGE-bearing Monchepluton intrusion. This $2.5 \mathrm{Ga}$ intrusion occurs in the north of the Baltic shield in the Murmansk region (NE Fennoscandia) (fig. 1; Huber, 2021; Bayanova et al., 2019; Pozhilenko et al., 2002).

\section{Methods}

Rock samples were collected from the Monchepluton in 2017-2019 to be used for preparing thin sections (see Fig. 1 for sampling points). They were examined using a Leica DM2500P optical polarizing microscope at the Department of Geology, Soil Science and Geoinformation of the Maria Curie-Skłodowska University in Lublin. Further, several rock-forming minerals (olivine, orthopyroxene, clinopyroxene, and plagioclase) were selected to analyze their shape by the following formula (1) (Petigen et al., 1992) using the QGIS and MS Excel software: 


$$
D=\frac{\left(\log _{\mathrm{x} 2}-\log _{\mathrm{x} 1}\right)}{\left(\log _{\mathrm{d} 2}-\log _{\mathrm{d} 1}\right)}
$$

where $\mathrm{x}_{1}$ and $\mathrm{x}_{2}$ correspond to the number of passes of the individual squares $\mathrm{x}_{1}$ and $\mathrm{x}_{2}$ along the contour of the shape, with $d_{1}$ and $d_{2}$ meaning their respective side lengths. The results of these measurements were correlated with those of the petrographic analysis for the rocks and their location in the massif. The data were interpreted accordingly.

\section{Results and Discussion}

Olivines in the Travyanaya rocks show higher fractal dimension coefficients while the highest ones are observed in the rocks where olivine is subject to corrosion (Nyud and Kumuzh'ya). Orthopyroxenes show the lowest coefficients in the orthopyroxenite rocks of the Kumuzh'ya, Nyud and eastern part of the Sopcha intrusions while the highest coefficients are found for the gabbronorites of the Nyud and Poaz massifs where these rocks are often exposed to the action of secondary processes. In case of clinopyroxenes, the lowest values were recorded in the rocks of the Nittis massif with tiny faceted crystals in the shear zones which are also typical of the Sopcha and Kumuzh'ya intrusions. The highest coefficients were established for the Nyud and Poaz rocks where the clinopyroxene is amphibolized. In case of plagioclases, the lowest coefficients were registered in the Kumuzh'ya and Sopcha rocks. The plagioclase forms there small minor crystals. On the contrary, the highest coefficients are recorded in large, sericitized plagioclases of the Poaz and Nyud gabbroids. The fractal dimension coefficients obtained for individual minerals correlate with their morphology in the rock.

Knowing the value for the base mineral (fresh, unchanged in a given type of rock), one may determine the precise percentage of how much the tested individual in the rock fits the above formula. By correlating these data with microscopic observations of samples, it is possible to find and scale the coefficient so that it corresponds to the ranges specified for the given minerals. For example, if a pure olivine from the Dunite block has a fractal dimension of 1.44 , an accessory olivine in the olivine gabbronorite - of 1.5 , and these values for olivine with reactive crowns and
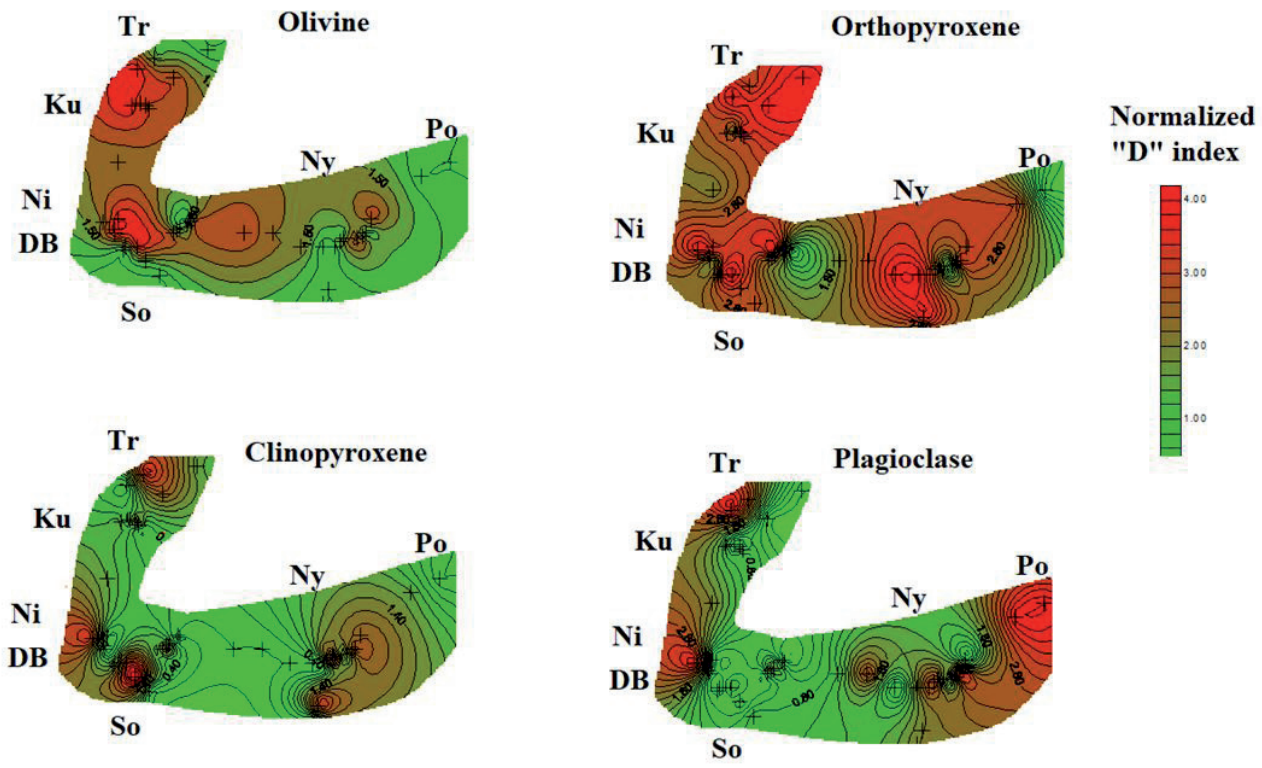

Fig. 2. Normalized fractal coefficients in various rocks-forming minerals from the Monchepluton.

Рис. 2. Нормализованные фрактальные коэффициенты в различных породообразующих минералах Мончеплутона. 
corrosion decay vary from 1.6 to 1.8 , the results can be scaled so that these intervals are more readable by assigning values of 1.00 to 4.00 to these minerals respectively. Similar data treatments can be applied to orthopyroxenes, clinopyroxenes and plagioclases where the zero value was inserted if the minerals were not counted. These values were superimposed on the coordinates of the discussed points and geological map of the Monchepluton massif (fig. 2).

In case of olivines, one can see that these minerals are often heavily corroded in the western part of the Monchepluton (Nittis-Kumuzh'ya-Travyanaya massifs or NKT) with abundant shear zones. The lowest coefficients for olivines are recorded at Nittis, Western Sopcha and Nyud's Critical Horizon where these minerals are euhedral.

In case of orthopyroxene, the situation drastically changes. This mineral shows high fractal dimension coefficients in the area of the NKT and Nyud massifs while Sopcha and Poaz expose much lower coefficients. This is due to numerous secondary processes occurring in the rocks in question (faults, sulfide veins, orthopyroxene mylonitization, and corrosion zones). This mineral, due to its presence in almost all the discussed rocks, is an indicator phase showing the degree of the secondary processes' maturity in the Monchepluton intrusion (fig. 2).

Clinopyroxenes generally yield low coefficients due to the fact that in the Sopcha and western Monchepluton massifs, if it occurs, it is a minor mineral represented by small laths. However, sometimes secondary crystallization of clinopyroxenes is so advanced that it forms a crystallizing phase in the orthopyroxene interstices that erodes these mineral. In the above rocks, clinopyroxenes show the highest fractal coefficient. The highest values are also established for plagioclases from the Poaz gabbroids where they form large crystals with visible sericitization processes.

It is supposed that the images in figure 2 demonstrate the degree of the secondary processes' advancement in the rocks in question. The presented normalized data can be summed up to show the average index for all the discussed minerals taken together.

The investigation of the averaged total values' distribution in all 4 discussed minerals from the Monchepluton (fig. 3) implies that more frequently these values significantly increase in the western part of the Monchepluton (NKT) due to the numerous secondary processes in the rocks in question. The case is similar in the Sopcha and Nyud massifs where diverse rocks and critical horizons are also influenced by multiple secondary processes. Relatively lower values were recorded in

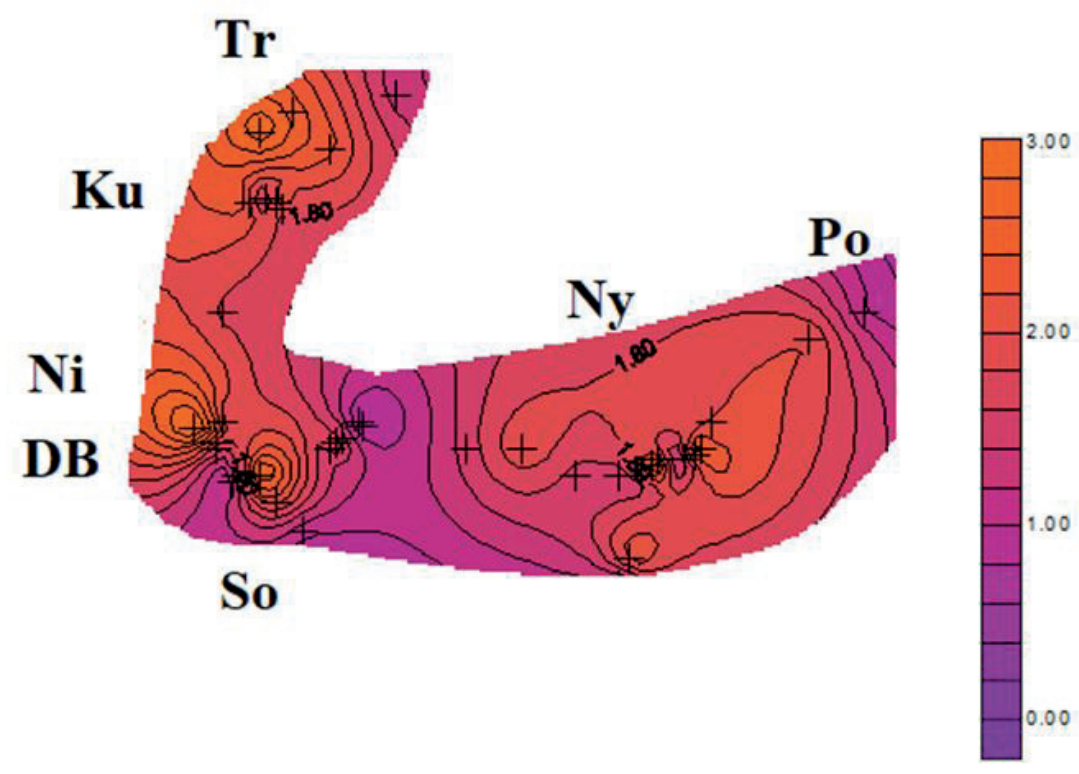

Fig. 3. Distribution of average total values in all 4 discussed minerals from the Monchepluton.

Рис. 3. Распределение средних суммарных значений по всем 4 обсуждаемым минералам Мончеплутона. 
the Poaz massif with gabbroids and in the eastern part of the Travyanaya and Sopcha massifs with orthopyroxenites where secondary processes are less common.

The described method demonstrates its universality and provides a possibility of mathematizing the morphology of the studied minerals. However, the aspect ratio itself does not depend on its orientation around the crystallographic axis of a mineral; it is merely a numerical indicator. Therefore, analysis of the fractal dimension also requires considering the petrographic nature of given rock-forming minerals. Petrographic analyses should precede fractal studies; otherwise, without this knowledge, distortions in the interpretation of the results may arise. Another essential argument lies in the fact that the shape of rock-forming minerals may be different in various intrusions depending on their genesis. Thus, studying several rock intrusions and generalizing the results demand taking this into account and possibly scaling individual results because mechanical comparison of these data may lead to erroneous conclusions.

\section{Conclusions}

The Monchepluton intrusion consists of peridotites and gabbroid rocks. It is a Paleoproterozoic layered PGE-bearing intrusion where such minerals as olivine, orthopyroxene, clinopyroxene, and plagioclase represent important indicators of the evolution of this intrusion, especially with regard to secondary processes that occurred there. The examination of the fractal dimension factor allows mathematizing the shape of these minerals and visualizing it in the form of maps. To compare these minerals with each other, one has to re-scale them so that the factor corresponds to the similar nature of their boundaries. This helps plotting a collective diagram that shows advancement of the secondary processes. However, the analysis and interpretation of these data require petrographic research and determination of the role of these minerals in the rocks. Although the method is relatively simple and repeatable, it requires careful interpretation because in different massifs these minerals may have various morphologies in the rocks which affect their fractal shape factor.

38 samples from the Monchepluton were selected. Each of the discussed samples was assigned a map (fig. 1). These are samples of dunites, harzburgites and orthopyroxenites from the NKT and Sopcha massifs, as well as gabbronorites and olivine gabbronorites from the Nyud and Poaz massifs. In each sample, several individuals of rock-forming minerals were examined, and then the results of the fractal dimension were averaged to one result for a given mineral in the rock sample. Generally, for the examined olivines, the lowest fractal dimension factor corresponds to euhedral olivine crystals from the critical horizons of the Sopcha and Nyud massifs.

\section{References}

1. Bayanova T., Korchagin A., Mitrofanov A., Serov P., Ekimova N., Nitkina E., Kamensky I., Elizarov D., Huber M. Long-Lived Mantle Plume and Polyphase Evolution of Palaeoproterozoic PGE Intrusions in the Fennoscandian Shield. Minerals. 2019. N. 9. V. 59. P. 3-22.

2. Chen T.L., Shi Z.L., Wen A., Yan D., Gou J., Chen J., Liu Y., Chen R. Multifractal characteristics and spatial variability of soil particle-size distribution in different land use patterns in a small catchment of the Three Gorges Reservoir Region, China. J. Mt. Sci. 2021. 18, 1. P. 111-125. DOI: 0.1007/s11629-020-6112-5.

3. Gerig A., Kruhl J.H., Caggianelli A. Quantification of Flow Patterns in Sheared Tonalite Crystal-melt Mush: Application of Fractal-geometry Methods. Journal Geological Society Of India. 2010. V. 75. P. 210-224. DOI: 0016-7622/2010-75-1-210.

4. Huber M. Dynamics of metamorphism processes by the fractal texture analysis of garnets, amphibole, and pyroxenes of Lapland Granulite Belt, Kola Peninsula. Journal of Biology and Earth Sciences. 2012. V. 2. P. 50-55.

5. Huber M., Hałas S., Serov P.A., Ekimova N.A., Bayanova T.B. Sm-Nd dating and stable isotope geochemistry of sulfides and U-Pb ages of layered intrusions from the northern part of the Baltic Shield, Mineralogia. 2012. V. 39. P. 107.

6. Huber M. Ewolucja kolsko-laplandzkiego pasa mobilnego na przykładzie platynonośnej paleoproterozoicznej intruzji warstwowanej moncheplutonu. Wyd. UMCS. 2021.

7. Kincal C., Koca M.Y., Ozden G., Demirbasa N. Fractal parameter approach on weathering grade determination of Cesme (Izmir, Turkey) tuffs. Bull. Eng. Geol. Environ. 2010. V. 69. P. 617-629. DOI 10.1007/s10064-010-0309-8. 
8. Lehmann P., Stahla M., Papritz A, Gygi A., Fluher H. A Fractal Approach to Model Soil Structure and to Calculate Thermal Conductivity of Soils. Transport in Porous Media. 2003. V. 52. P. 313-332.

9. Martin M.A., Reyes M. A Fractal Interaction Model for Winding Paths through Complex Distributions: Application to Soil Drainage Networks. Pure Appl. Geophys. 2008. V. 165. P. 1153-1165. DOI 10.1007/s00024-004-0351-7.

10. Mitrofanov F.P., Smolkin V.F. Stratified intrusions of the Monchegorsk ore region: petrology, mineralization, isotopy, deep structure. In 2 parts. Ed. Apatity: Kola Scientific Center, Russian Academy of Sciences. 2004. P. 344.

11. Mohammadi A., Khakzad A., Omran N.R., Mahvi M.R., Moarefvand P., Afzal P. Application of number-size (N-S) fractal model for separation of mineralized zones in Dareh-Ashki gold deposit, Muteh Complex, Central Iran. Arab J Geosci. 2013. V. 6. P. 4387-4398. DOI 10.1007/s12517-012-0662-y.

12. Petigen H.O., Jürgens H., Saupe D. Fractals for the Classroom. Springer-Verlag N.Y. 1992. V. 1. P. 546.

13. Pozhilenko V.I., Gavrilenko B.V., Zhirov D.V., Zhabin S.V. Geology of the ore regions in the Murmansk region, Apatity. 2002. P. 360.

14. Singh A, K, Upadhyay D, Pruseth K.L., Mezger K., Nanda J.K., Maiti S., Saha D. Shock Metamorphic Features in the Archean Simlipal Complex, Singhbhum Craton, Eastern India: Possible Remnant of a Large Impact Structure. Journal Geological Society Of India. 2021. V. 97. P. 35-47. DOI: 10.1007/s12594-021-1623-4.

15. Voytekhovsky Y.L., Shpachenko A.K., Skiba V.I. Cell-zonal textures of tinguaites from the Kola Peninsula. Geol Rundsch. 1997. V. 86. P. 531-538.

16. Zheru Z., Huahi M., Cheng Q. Fractal Geometry of Element Distribution on Mineral Surfaces. Mathematical Geology. 2001. 33, 2.

17. Zhengli M., Jianqing L., Yang B. The geochemical multi-fractal characteristics and mineralization of the Dehelongwa copper-gold deposit. Chin. J. Geochem. 2014. V. 33. P. 280-288. DOI: 10.1007/s11631-014-0689-89. 